\title{
DEVELOPMENT OF CYLINDRICAL FILTERS USED IN \\ CONVENTIONAL COTTON OPENING LINES
}

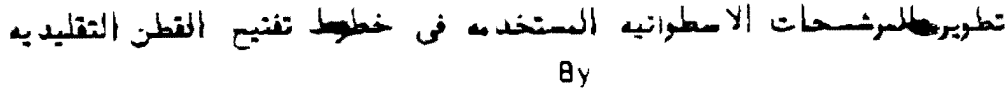

HEMOAN A. ABOULTALEB

Textile Engineering Dept., Faculty of Engineering, Mansoura University, Mansoura, EGYPI.

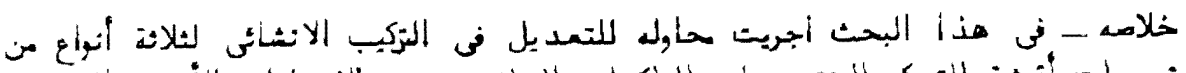

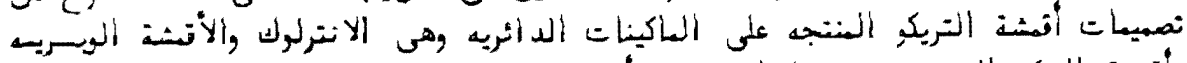

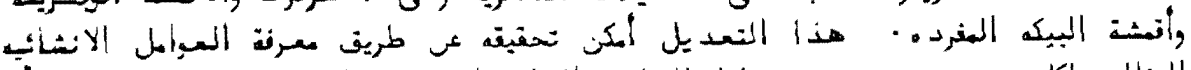

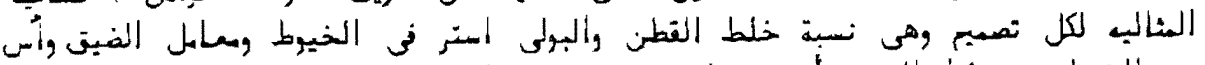

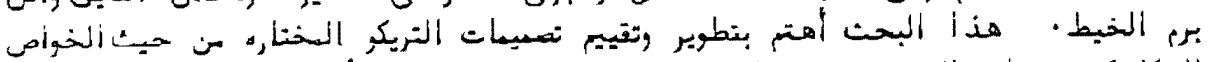

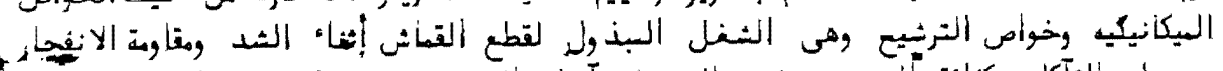

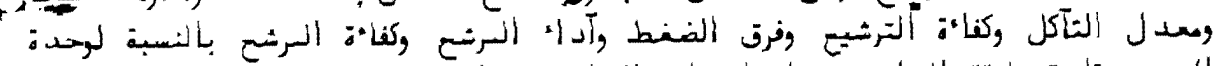

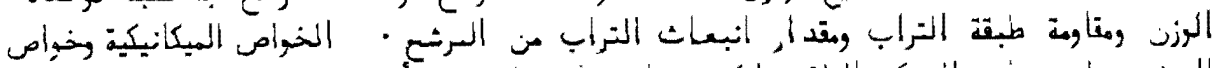

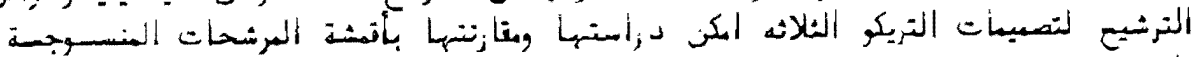

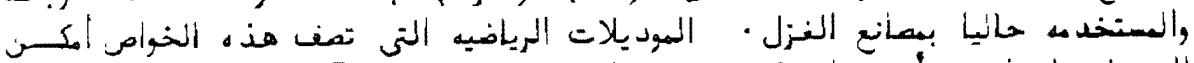

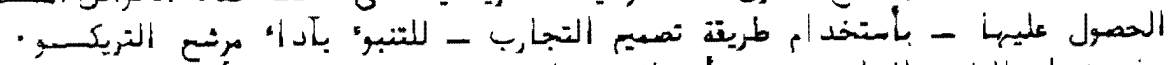

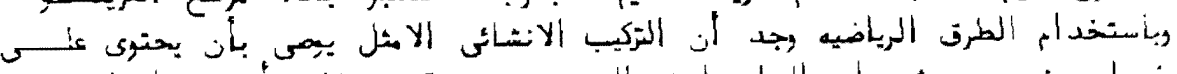

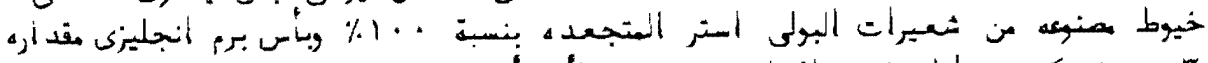

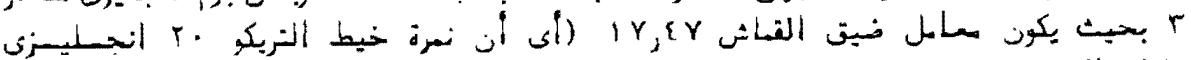

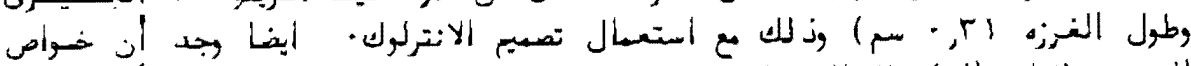

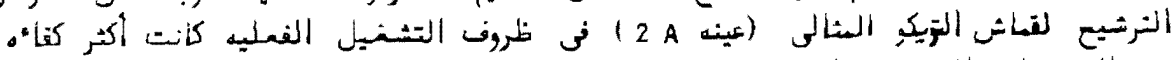

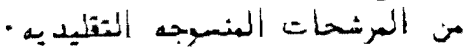

ABSIRACT- In this research an attempt has been made to modify the construction of a number of circular - knitted structures 1.e. interlock, plle fabrics and single piqué. This modification could be achieved by means of knowing the aptinum constructional factors of each knitted structure such as polyester/ cotton blend ratio, tightness factor and yarn twist multiplier. Ihis research is concerned with the develapment and evaluation of the selected knit.ted structures for mechanical and dust - filtration applications with regard to specific work of rupture, bursting pressure, rate of abrasion, filtration efficiency $(\boldsymbol{l})$, pressure drop $(\Delta P), f_{1}$ ther performance $(\gamma)$, filter efficiency per unit mass $(I / M)$, specific cake resistance $(K)$ and dust emission or outlet concentration ( $\mathrm{CO}$ ). The mechanical and filtration propertzes of these structures are studied and compared with those of similar woven filter fabr ics. Mathematical models describing these properties could be obtained, by using factorial design method, for predicting the kmitted filter performance. By using the mathematical methods, it was found that the optimum fabric con struction is recommended to be contained $100 \%$ crimped polyester fibres yarn, 17.47 tightness factor (i.e. yarn count $20 \mathrm{Ne}$, loop length $0.31 \mathrm{~cm}$ ) and $3 \alpha_{\mathrm{e}}$ twist multiplier with using interlock structure. Also, $\mathrm{LL}$ is observed that the fultration characteristics of the optimum structure (Sample 2A) in the actual operaling conditions were more efficient than conventional woven $I_{l} l-$ ters. 


\section{INTRODUCTION}

When a bale of cotton enters a spinning mlll, it brings with it a stored potential to release fine duse. This dust is either present as fine dust and escapes when is int is opened or it is created when mechanical actions of processing machines break trash and fibres. Alr currents generated by the machine cause the fine dust to enter the environmental air in the spinning inill, especially in the blowing room. When the cotton dust enters the mill alr, worker health may be adversely affected [ 1$]$. The essential principle of fabric filtration is to cause dusty gas to flow through elements of a permeable textile fabric by elther pressure or suction and to retain the dust on the fabric.

The woven filter (article 3015) used in the conventional cotton opening lines in Mehalla Spinning and Weaving Company has the following specifications: $100 \%$ cotton, plain weave $1 / 1$, average fabric width $202.5 \mathrm{~cm}$, ends per inch 60 , picks per inch 60, warp yarn count 14.6/1, weft yarn count $14 / 1$, twist factor for warp yarns $3.7 \alpha_{\mathrm{e}}$, twist factor for weft yarns $3.3 \alpha_{\mathrm{e}}$ and weight per unit area $202 \mathrm{~g} / \mathrm{m}^{2}$. The constructional characteristics of these conventional woven filters create condir.ians not only for high a2c permeability but also for a high level of dust penetiation which has an aciverse effect on dust retention. The dust should be filtered out of the alr with fabrics which have lower strength but are capable of withstanding cleaning by mechanical means. The requirements of the filtermaking process as well as economic consideratlons probably explein this lake of variety in commercial filters. In order to retaln dust partıcles, the filter requires other properties, including uniformity and firmness in structure, high filtration efficiency, low pressure drop with prescribed limits and high production rates.

Woven and needle felt fabrics are commonly used for industrial dust collection purposes. Such fabrics, after suttable finishing processes, pro$\checkmark$ ide a high filtration efficiency coupled with a dimensional stability that enables them to withstand the mechanical forces dur.ing the various types of cleanıng process, i.e.. shake, reverse air or pulse. However, in the case of both woven and needle felt fabrics, costly seaming operations have to be carried out to produce tubular filter sleeves. This is labour-intensive and can result in (a) weaker areas in the filter and (b) reduction in airpermeability at the seam. Both these factors can result in an uneven filtration performance of the sleeve. Tubular - knitted fabrics have the advantage that they ran be produced to the required diameter and shape. There are, however a number of limitions inherent in a weft knitted fabric, such as high extension and low recovery when subjected to pressure as well as the anistropic nature of the fabric properties, which will render it useless as filter media. These have to be overcome before such fabrıcs can be serlously considered for filtration [2]. Knitted fabrics have not been seriously considered because of their high extensibility when subjected to these forces that are involyed during filtration. It is also well knom that the tensile properties of most weft $\rightarrow$ nitted structures, especially single-jersey structures are anisotropic with a higher extensibility and a lower initial modulus in the coursewise direction than the walewise direction [3]. However, these limitions have to a large extent been overcame in the ather chosen structures, i.e., inter lock, p.l le faorics and single piqué which can be seriously considered for filtration.

The object of this research is concerned with the development of a number of ciccular-knitted structures for dust-filtration applications with regard tc the mechanical and filtraticn properties. The constiuctional faltors chosen here for analysis were polyester/cotton blend ratıo, tightness factor and yarn lwist mult iplier. 


\section{2- EXPERIMENTAL WORK}

\section{2-1. Test Samples:}

A range of 24 double-jersey fabrics was"produced on cifcular knitting machines to change values of loop length and tightness factor for three different structures, interlock, pile fabrics and single piqué.

Yarn length per stitch could be periodically checked using the following formula [4]:

$$
\text { Loop length }(1)=\frac{\text { speed of yarn }}{\text { machine r.p.m }} \times \frac{1}{\text { no. of needles }}
$$

Fabrics were produced on a Mair/C (German machine) 36-feed; 20-gauge $1728 \times 1728$ needle double - Jersey machine. Fabrics were made of polyester and cotton fibres in which two levels each of polyester/cotton blend percentage, tightness factor and yarn twist multiplier were represented. Specif $f_{-}$ cations of the fabcics produced are detailed in rable (1), and the notations of the structures produced are given in $F_{19}$. (1).

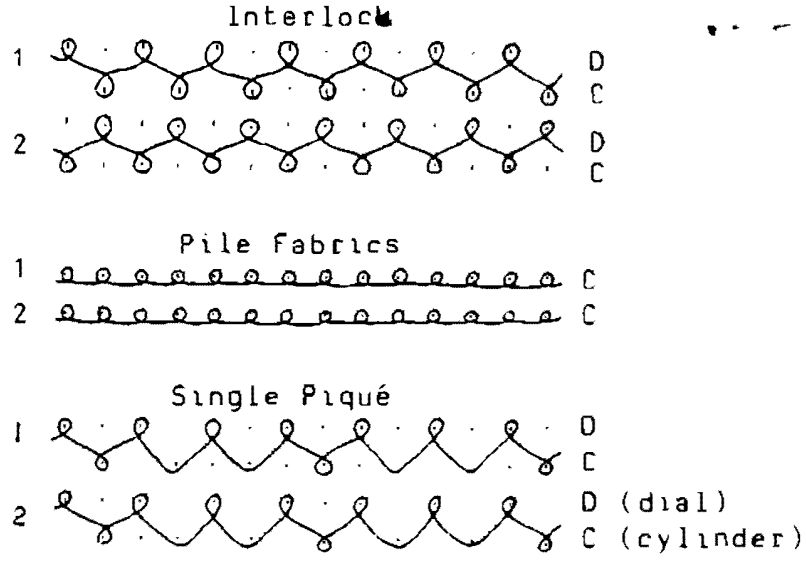

F Lg. (1): Notations of structures used for tested samples.

2-2. Experimental Design:

The experiments for each structure were planned according to the facto rial design $(23)[5,6]$ for the three variables $i . e$. , polyester/cotton blend percentage $\left(x_{1}\right)$, tightness factor $\left(x_{2}\right)$ and twist multipl Ler $\left(x_{3}\right)$. Tightness factor is defined as $I F=\sqrt{T} / 1$, where $T$ is the yarn linear density in tex and 1 is the average loop length in cm [7]. By using small changes in yarn count. and loop length, fabric tightness can be varied between approximately 10 and $22 \mathrm{~g} / \mathrm{m} 3 / 2$. The range of variation of these factors is given in Table (2) and the experimental plan is given in Table (3).

2-3. Iest Methods:

2-3-1. Relaxation and Conditioning:

The knitted fabrics produced in Cairo Garments and Knitting Company (Iricona) were tested in the laborator les of Textile Engineering Dept., Mansoura University, Facult,y of Engineering in ordec to determine the most important properties such as specific work of ruplure, bursting resistance, rate of abrasion, filtration effictency, pressure drop, filter perfocmance, filtef efficiency per unit mass, specific cake resistance and dust emission. These properties could be measured after steam-relaxed condition and heal:-setting process for crimped polyester fibres fabric at $170^{\circ} \mathrm{C}$ and after steaming cotton knitted fabric at $90^{\circ} \mathrm{C}$. 
Table (1): Structural Detalled of Knitted Samples

\begin{tabular}{|c|c|c|c|c|c|c|c|c|c|}
\hline $\begin{array}{l}\text { Name of } \\
\text { Structure }\end{array}$ & $\begin{array}{c}\text { Sample } \\
\text { Code }\end{array}$ & $\begin{array}{c}\text { Xarn } \\
\text { Material }\end{array}$ & $\begin{array}{c}\text { Yarn } \\
\text { Count } \\
(\text { Tex })\end{array}$ & $\begin{array}{c}\text { toop } \\
\text { Length } \\
(\mathrm{cm})\end{array}$ & $\mid \begin{array}{c}\text { Tightness } \\
\text { Factor } \\
\left(g^{\frac{1}{2}} / \mathrm{m}^{2} / 3\right)\end{array}$ & $\begin{array}{l}\text { No. of } \\
\text { Courses/ } \\
(\mathrm{cm})\end{array}$ & $\begin{array}{l}\text { Now of } \\
\text { Wales/ } \\
(\mathrm{cm})\end{array}$ & $\begin{array}{l}\text { Thickness } \\
(\mathrm{mm}) \text { at } \\
5 \mathrm{~g} / \mathrm{cm}^{2}\end{array}$ & $\begin{array}{l}\text { We lght } \\
\left(\mathrm{g} / \mathrm{m}^{2}\right)\end{array}$ \\
\hline Inter lock & $\begin{array}{l}1 A \\
2 A \\
3 A \\
4 A \\
5 A \\
6 A \\
7 A \\
8 A\end{array}$ & $\begin{array}{l}P^{*} \\
C \\
C \\
C \\
P \\
p \\
C \\
P\end{array}$ & $\begin{array}{l}19.68 \\
29.53 \\
19.68 \\
29.53 \\
19.68 \\
29.53 \\
19.68 \\
29.53\end{array}$ & $\begin{array}{l}0.444 \\
0.310 \\
0.444 \\
0.310 \\
0.444 \\
0.310 \\
0.444 \\
0.310\end{array}$ & $\begin{array}{r}9.99 \\
17.52 \\
9.99 \\
17.52 \\
9.99 \\
17.52 \\
9.99 \\
17.52\end{array}$ & $\begin{array}{r}8.66 \\
17.32 \\
9.45 \\
18.11 \\
8.66 \\
16.54 \\
9.54 \\
17.32\end{array}$ & $\begin{array}{l}12.99 \\
11.02 \\
12.20 \\
10.24 \\
13.78 \\
11.02 \\
12.60 \\
11.42\end{array}$ & $\begin{array}{l}1.62 \\
1.24 \\
1.38 \\
1.28 \\
1.50 \\
1.42 \\
1.48 \\
1.29\end{array}$ & $\begin{array}{l}198 \\
334 \\
189 \\
350 \\
201 \\
345 \\
216 \\
360\end{array}$ \\
\hline $\begin{array}{l}\text { Pule } \\
\text { fabrics }\end{array}$ & $\begin{array}{l}18 \\
28 \\
38 \\
4 B \\
5 B \\
68 \\
7 B \\
8 B\end{array}$ & $\begin{array}{l}P \\
C \\
C \\
6 \\
p \\
p \\
c \\
p\end{array}$ & $\begin{array}{l}19.68 \\
29.53 \\
19.68 \\
29.53 \\
19.68 \\
29.53 \\
19.68 \\
29.53\end{array}$ & $\begin{array}{l}0.428 \\
0.380 \\
0.428 \\
0.380 \\
0.428 \\
0.380 \\
0.428 \\
0.380\end{array}$ & $\begin{array}{l}10.36 \\
14.30 \\
10.36 \\
14.30 \\
10.36 \\
14.30 \\
10.36 \\
14.30\end{array}$ & $\begin{array}{l}11.02 \\
12.60 \\
11.02 \\
12.60 \\
11.02 \\
11.81 \\
11.02 \\
11.81\end{array}$ & $\begin{array}{l}9.06 \\
8.66 \\
9.06 \\
8.66 \\
9.06 \\
8.66 \\
9.06 \\
8.66\end{array}$ & $\begin{array}{l}2.28 \\
2.62 \\
2.40 \\
2.67 \\
2.28 \\
2.70 \\
2.48 \\
2.71\end{array}$ & $\begin{array}{l}252 \\
412 \\
230 \\
429 \\
263 \\
417 \\
251 \\
449\end{array}$ \\
\hline $\begin{array}{l}\text { Single } \\
\text { Piqué }\end{array}$ & $\begin{array}{l}1 C \\
2 C \\
3 C \\
4 C \\
5 C \\
6 C \\
7 C \\
8 C\end{array}$ & $\begin{array}{l}p \\
C \\
C \\
C \\
p \\
p \\
C \\
p\end{array}$ & $\begin{array}{l}19.68 \\
29.53 \\
19.68 \\
29.53 \\
19.68 \\
29.53 \\
19.68 \\
29.53\end{array}$ & $\begin{array}{l}0.263 \\
0.246 \\
0.263 \\
0.246 \\
0.263 \\
0.246 \\
0.263 \\
0.246\end{array}$ & $\begin{array}{l}16.87 \\
22.09 \\
16.87 \\
22.09 \\
16.87 \\
22.09 \\
16.87 \\
22.09\end{array}$ & $\begin{array}{l}11.81 \\
18.90 \\
12.60 \\
15.75 \\
12.60 \\
17.32 \\
12.60 \\
17.32\end{array}$ & $\begin{array}{r}10.24 \\
9.84 \\
9.45 \\
10.24 \\
9.45 \\
9.84 \\
10.24 \\
9.45\end{array}$ & $\begin{array}{l}1.45 \\
1.47 \\
1.33 \\
1.47 \\
1.23 \\
1.42 \\
1.32 \\
.48\end{array}$ & $\begin{array}{l}175 \\
322 \\
173 \\
335 \\
184 \\
324 \\
178 \\
350\end{array}$ \\
\hline
\end{tabular}

Table (2): Pange of Varsation for Studied Factors

\begin{tabular}{|c|c|c|c|}
\hline Factor Level & & $\begin{array}{c}\text { min value } \\
(-1)\end{array}$ & $\begin{array}{c}\max \text { value } \\
(+1)\end{array}$ \\
\hline $\begin{array}{l}x_{1}-\text { polyester/cotton blend }(\%) \\
x_{2}-t \text { ightness factor }\left(g^{1 / 2} / \mathrm{m}^{3 / 2}\right) \\
x_{3} \text {-twist muIt ipIler }(\alpha e)\end{array}$ & $\begin{cases}\text { for } & (A) \\
\text { for } & (B) \\
\text { for } & (C)\end{cases}$ & $\begin{array}{c}0 / 100 \\
9.99 \\
10.36 \\
16.87 \\
3\end{array}$ & $\begin{array}{l}100 / 0 \\
17.52 \\
14.30 \\
22.09 \\
3.5\end{array}$ \\
\hline
\end{tabular}

Table (3): Experimental Plan of Studzed Factors For Each Structure

\begin{tabular}{c|r|r|r}
\hline \multirow{2}{*}{ Exp. No. } & \multicolumn{3}{|c}{ Coded Levels of factors } \\
\cline { 2 - 4 } & $x_{1}$ & $x_{2}$ & $x_{3}$ \\
\hline 1 & 1 & -1 & -1 \\
3 & -1 & 1 & -1 \\
4 & -1 & -1 & 1 \\
5 & -1 & 1 & 1 \\
6 & 1 & -1 & -1 \\
7 & 1 & -1 & -1 \\
8 & 1 & 1 & 1 \\
\hline
\end{tabular}


2-3-2. Mechanical Properties:

\section{(i) Specific Work of Rupture $(g / t e x)$}

Here each fabric was tested on the Lloyd Universal Tester. Five

- fabric specimens, with $140 \mathrm{~mm} \times 50 \mathrm{~mm}$, were cut with the long side parallel to. the wales. The gauge length between the jaws was set at $100 \mathrm{~mm}$ and the cros-shead speed was set at $50 \mathrm{~mm} / \mathrm{min}$ during extension and at $100 \mathrm{~mm} / \mathrm{min}$ during recovery. From these tests, the fabric specific work of rupture in wale direction was determaned [8]. The results obtained are shown in rable (4).

\section{(11) Specific Burgtıng Pressure $\left(\mathrm{Kg} / \mathrm{cm}^{2}\right)$}

The bursting tests of knitted fabrics were carried out on the Hydraulic Bursting Strength Tester using diaphragm test. The mean error of the readings of that tester does not exceed 1 per cent of the actual load. The results obtained are shown in Table (4).

\section{(iii) Rste of Abrasion (\%)}

The fabrics were tested by means of Turbo Wear Tester using Impeller Tumble Method. For testing the abrasion (percentage loss of weight due to abrasion), the following conditions were used: rested spectmen $5 \times 5 \mathrm{~cm}$, abra" sion time, $5 \mathrm{~min}$ and number of specimens from each sample, 10. The results obtained are shown in raole (4).

\section{2-3-3. Filtration Properties:}

The selection of fabric filter media depends to a great extent on many primary factors such as: filtration efficiency ( $?$ ), pressure drop ( $\Delta P)$, filter performance $(\gamma)$, filter efficiency per unit mass $(\eta / M)$ and specific cake resıstance $(K)$ and dust emission or out let concentration (Co).

\section{(i) Filtration Efficiency}

The measurement of filtration efficiency of fabrics is the main object of this work. It is tested on the apparatus shown in $\mathrm{F}$ ig. (2) and reference [9], where volumetrlc flow rate in the apparatus is kept constant at $183 \mathrm{~cm}^{3} / \mathrm{sec}$ (11 litre/mLn) through area of test filter equal to $15 \mathrm{~cm}^{2}$ for three minutes using a very fine dust $(32 \mu)$. However, filtration efficiency was abtained by weighing the amount of collected dust on the main filter and on a filtration paper through which was passed the full flow of alr issuing from the main filter. Filtration efficiency ( $\eta$ ) was determined from the following expression:

$$
\eta(\%)=\left(\frac{M_{C}}{M_{C}+M_{p}}\right) \times 100,
$$

where $M_{p}$ and $M_{p}$ are the weights of Just collected on the main filter and filtration paper, respectively.

1- pıpe

$2 \& 9$ - regulator

3\&10-flowmeter

$4 \& 11-p r e s s u r e$ gauge

5- fabric sample

6\&14-valve

7- manometer

o- blower

12- filtration paper

13- dust feeding device

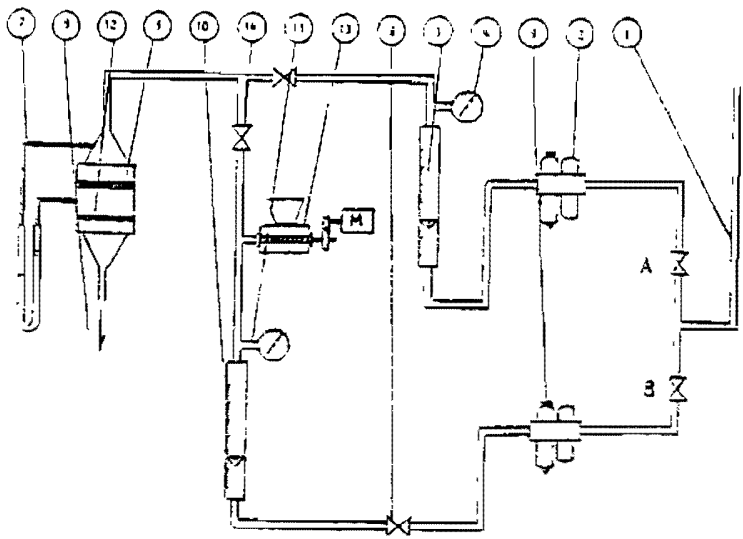

Fig. (2): A Schematic diaqran of gas filtration apparatus. 
Table (4): Measurements of Mechanical and Filtration Properlices of Main Experiment Samples

\begin{tabular}{|c|c|c|c|c|c|c|c|c|c|}
\hline & Mect & Ianical Pro & operties & & & Fil & tration & Propert & ies \\
\hline $\begin{array}{l}\text { Sample } \\
\text { Code }\end{array}$ & $\left\{\begin{array}{l}\text { Sp.w.r. } \\
(g / \text { tex })\end{array}\right.$ & $\begin{array}{l}\text { Bursting } \\
\text { pressure. } \\
\text { (Kg/cm2) }\end{array}$ & $\begin{array}{c}\text { Rate of } \\
\text { abrasion, } \\
\left(y_{0}\right)\end{array}$ & $\begin{array}{l}7, \\
(\approx)\end{array}$ & $\begin{array}{l}\Delta P \text {, } \\
\text { mm of } \\
\text { water }\end{array}$ & $\gamma$ & $7 / M$ & $\begin{array}{c}\text { K, } \\
\text { (N.sec) } \\
\text { g.cm) }\end{array}$ & $\begin{array}{c}C_{0}, \\
\left\langle q / \mathrm{cm}^{3}\right\rangle\end{array}$ \\
\hline & $y_{1}$ & $y_{2}$ & $y_{3}$ & $y_{4}$ & $y_{5}$ & $y_{6}$ & $y_{7}$ & $y_{8}$ & $y_{9}$ \\
\hline $\begin{array}{l}1 A \\
2 A \\
3 A \\
4 A \\
5 A \\
6 A \\
7 A \\
8 A\end{array}$ & $\begin{array}{r}8.84 \\
7.74 \\
6.26 \\
7.84 \\
10.65 \\
11.45 \\
6.82 \\
10.90\end{array}$ & $\begin{array}{r}9.6 \\
21.4 \\
9.15 \\
21.0 \\
10.7 \\
22.6 \\
9.32 \\
23.5\end{array}$ & $\begin{array}{r}4.7 \\
8.0 \\
11.3 \\
5.2 \\
4.4 \\
4.0 \\
8.2 \\
2.8\end{array}$ & $\begin{array}{l}86.8 \\
96.2 \\
84.3 \\
92.9 \\
85.4 \\
97.6 \\
88.2 \\
91.7\end{array}$ & $\begin{array}{r}2.0 \\
38.8 \\
6.0 \\
30.0 \\
3.0 \\
9.8 \\
3.4 \\
10.2\end{array}$ & $\begin{array}{r}10.140 \\
0.941 \\
3.090 \\
0.879 \\
6.409 \\
3.789 \\
6.281 \\
2.440\end{array}$ & $\begin{array}{l}0.439 \\
0.288 \\
0.446 \\
0.265 \\
0.425 \\
0.283 \\
0.408 \\
0.255\end{array}$ & $\begin{array}{l}0.134 \\
3.000 \\
1.205 \\
1.384 \\
0.092 \\
0.454 \\
0.191 \\
0.590\end{array}$ & $\begin{array}{l}0.691 \times 10^{-7} \\
0.042 \\
2.407 \\
0.303 \\
1.061 \\
0.576 \\
0.570 \\
0.315\end{array}$ \\
\hline $\begin{array}{l}18 \\
28 \\
38 \\
48 \\
58 \\
68 \\
78 \\
88\end{array}$ & $\begin{array}{l}2.9 \\
2.4 \\
2.3 \\
2.4 \\
2.6 \\
3.0 \\
2.2 \\
2.6\end{array}$ & $\begin{array}{r}7.3 \\
9.8 \\
6.3 \\
10.3 \\
7.3 \\
11.4 \\
6.2 \\
10.4\end{array}$ & $\begin{array}{l}5.5 \\
8.7 \\
8.3 \\
9.4 \\
7.7 \\
5.1 \\
8.8 \\
4.5\end{array}$ & $\begin{array}{l}90.6 \\
96.6 \\
90.8 \\
90.8 \\
86.2 \\
96.5 \\
85.0 \\
92.0\end{array}$ & $\begin{array}{r}4.6 \\
23.6 \\
6.6 \\
21.8 \\
4.6 \\
11.8 \\
6.0 \\
11.2\end{array}$ & $\begin{array}{l}0.460 \\
1.433 \\
3.615 \\
1.094 \\
4.305 \\
2.841 \\
3.162 \\
2.255\end{array}$ & $\begin{array}{l}0.360 \\
0.234 \\
0.395 \\
0.212 \\
0.328 \\
0.231 \\
0.339 \\
0.205\end{array}$ & $\begin{array}{l}0.389 \\
0.408 \\
0.047 \\
1.420 \\
0.368 \\
0.428 \\
0.064 \\
0.677\end{array}$ & $\begin{array}{l}0.291 \times 10^{-7} \\
0.315 \\
0.796 \\
0.206 \\
0.449 \\
0.188 \\
0.242 \\
0.249\end{array}$ \\
\hline $\begin{array}{l}1 C \\
2 C \\
3 C \\
4 C \\
5 C \\
6 C \\
7 C \\
8 C\end{array}$ & $\begin{array}{l}5.46 \\
5.13 \\
4.62 \\
5.18 \\
7.01 \\
5.98 \\
4.87 \\
5.54\end{array}$ & $\begin{array}{r}13.0 \\
16.2 \\
10.0 \\
16.1 \\
13.3 \\
19.9 \\
9.7 \\
19.4\end{array}$ & $\begin{array}{r}7.3 \\
10.4 \\
9.9 \\
7.2 \\
4.3 \\
5.0 \\
9.5 \\
4.4\end{array}$ & $\begin{array}{l}79.2 \\
98.6 \\
84.5 \\
91.5 \\
85.2 \\
97.4 \\
96.2 \\
95.3\end{array}$ & $\begin{array}{l}3.0 \\
8.6 \\
4.4 \\
7.2 \\
3.0 \\
5.0 \\
3.8 \\
5.0\end{array}$ & $\begin{array}{l}5.234 \\
4.964 \\
4.208 \\
3.424 \\
6.368 \\
7.299 \\
8.606 \\
6.115\end{array}$ & $\begin{array}{l}0.453 \\
0.306 \\
0.487 \\
0.273 \\
0.463 \\
0.301 \\
0.540 \\
0.272\end{array}$ & $\begin{array}{l}0.045 \\
0.021 \\
0.029 \\
0.054 \\
0.042 \\
0.030 \\
0.021 \\
0.047\end{array}$ & $\begin{array}{l}1.558 \times 10^{-7} \\
1.261 \\
9.462 \\
0.533 \\
3.754 \\
1.055 \\
2.061 \\
0.582\end{array}$ \\
\hline $\begin{array}{l}\text { Conv. } \\
\text { Filter }\end{array}$ & 1.36 & 22.97 & 45.4 & 95.92 & 9.0 & 3.554 & 0.522 & 0.522 & $0.444 \times 10^{-7}$ \\
\hline
\end{tabular}

(i1) Pressure Orop $(\Delta P)$

Pressure drop is an important parameter in the design of tubular filters and for practical reasons must fall within prescribed limits. These limits control, to a large degree, the filtration efficiencies that are abtaunable. Raising the pressure drop improves the filtration efficiency ( 7 ) and thus reduces the number of dust particles that penetrate the filter. This implies that any increase in the value of filtration efficiency would require a somewhat larger increase in the pressure drop and filter mass. In the filtration experiment.s the pressure drop was registrated for three minut.es. Pressure drops were determined in $\mathrm{mm}$ of water using filtration apparatus in which water manometer and an air-flow rate of $183 \mathrm{~cm} / \mathrm{sec}$ was used. $(1 \mathrm{~mm}$ of water $=9.8 \mathrm{~Pa}$ ).

\section{(iil) Filter Performance ( $\gamma$ )}

Several criteria may be used to evaluate the performance of dust. filler. Percentage filliration efficiency ( 7 : gives a direct measure of the proportion of dust particles retained by lhe filter and an indirect measure of those that penetrate the filter. However, ( 7 ) falls to account for the 
effect of filter parameters, such as pressure drop and mass, that are of importance in filter design. Chen [10] derived the following relation between filter êfficlency $(7)^{*}$ and pressure drop $(\Delta P)$ as à criterion of filter performance:

$$
\gamma=\frac{-\ln (1-7)}{\Delta p}
$$

where $(\Delta P)$ is a pressure drop in $\mathrm{cm}$ of water.

A higher value of $(\gamma)$ denotes a more effective filter.

\section{(iv) Filter Efficiency Per Unit Mass ( $\eta / M)$}

Filter performance can also be based on the filtration efficiency per unit mass of filter material $(T / M)$. For a given fibre type, this expr ession affords an assessment of the collection efficienc les of the individual fibres and provides a basis for comparing the cost of filters that have equ1valent filtration efficiencies. In this work. the above terms have been employed to define the performance of dust filters [11]; where $M$ is the werght per untt area of the filter fabric, $\mathrm{g} / \mathrm{m}^{2}$.

\section{(v) Specıfic Cake Resistance (K)}

The filter drag is defined as the pressure drop $(\Delta P)$ divided by the face velocity $(V)$. The face velocity is given by [12]:

$$
V=\frac{Q}{A}, \quad \mathrm{~cm} / \mathrm{sec}
$$

where $Q$ is the volumetric flow rate through the filter, $\mathrm{cm}^{3} / \mathrm{sec}$ and A is the area of fliter, $\mathrm{cm}^{2}$

The effectiee drag $\left(\Delta P_{2} / V\right)$ is defined as the drag after the filter has been stabilized. It was measured at the beginning of the filtration process. The terminal drag ( $\triangle P f / V$ ) was measured at the end of the filtration process ( 3 minutes). The specific cake resistance $(K)$ may be written as follows:

$$
K=\frac{S}{W}=\frac{(\Delta P f / V)-\left(\Delta p_{1} / V\right)}{M c / A}, N \cdot \sec / g \cdot c m
$$

where $S$ is the $d r a g\left(N \cdot \sec / m^{3}\right)$, and $W$ is the mass of cake per unit area $\left(\mathrm{g} / \mathrm{cm}^{2}\right)$.

(vi) Dust Emission or Dutlet Concentration (Co)

The out let concentration ( $C O$ ) Ls the ratio of the mass of dust passed by the filter to the volume of gas passed during a filtration cycle. It may be expressed as follows:

$$
\mathrm{Co}=\mathrm{Mp} / \mathrm{Q} . \mathrm{tc}, \mathrm{g} / \mathrm{cm}^{3}
$$

where to is the time of filtration process ( $\mathrm{sec}$ ), and Mp is the dust mass passed by the ma in filter (gram).

Dutlet concentration was evaluated at the end of the process of filtration $(3 \mathrm{~min}$.) 


\section{RESULTS AND DISCUSSION}

\section{- 3-1. Experimehtal Analysis?}

The resuits obtained for mechanical properties: specific work of rupture, bursting strength, rate of abrasion and filtration properties: filtration efficlency ( 7 ), pressure drop ( $\Delta P$ ), filter performance $(\gamma)$, filter performance per unit mass $(T / M)$, specific cake resistance $(K)$ and dust emission or out let concentration (Co) listed in Table (4) were fed to IPM Computer, and regression coefficlents were determined. The coefficlents were tested for significance at the 95\% significance level. The response-surface equations for the various fabric properties are given in Tables $(5-7)$ with the correlation coefficlents between the experimental values and the calculated values obtained from the response surface equation. The response surface agrees fairly with the experimental data as can be seen from the high correlation coefficients. Contour maps and three - dimensional plots of the effect of tightness factor and twist multiplier on the mechanical and filtration properties for both polyester and cotton fabrics were constructed by using the response -

- surface equations. To understand this interaction, the graphical presentation shown in Figures $(3-56$ ) was used. Such dependence can be represented as shown by a surface in a three - dimensional plot for a two-factor interaction.

\section{3-2. Parameters that Affect the Filter Behaviour:}

\section{3-2-1. Polyester/cotton blend percentage:}

\section{(i) Interlock Structure}

Figures $(3-20)$ show that the specific work of rupture, bursting strength, rate of abrasion, filtration efficiency ( $\eta$ ), pressure drop ( $\Delta P$ ), filter performance ( $\boldsymbol{\gamma}$ ), filtration efficiency per unit mass ( $\eta / M$ ), specific cake resistance $(K)$ and out let concentration $(C O)$ for cotton knitted fabrics at the level $\left(x_{1}=-1\right)$ and for polyester knitted fabrics at the level $\left(x_{1}=+1\right)$ using interlock structure. Polyester knitted fabrics, as expected, show higher spec if lc work of rupture, bursting strength, fliter performance $(\gamma)$, filtration efficiency per unit mass $(\eta / M)$ than cotton knitted fabrics. Also polyester knitted fabrics show lower rate of abrasion, pressure drop, specific cake resistance and outlet concentration than cotton knitted fabrics. The effect of fibre type on filter behaviour can be interpreted in terms of the change of crimp level. Use of crimped fibres (polyester) rather than uncrimped fibres (cotton) improve drag characteristics. Also high tenacity and breaking extension of polyester flores improve the mechanical properties. Also cross-sectional shape of mature cotton fibres is nearly round such as the round cross-sectional of polyester fibres. Therefore, the filtration efficiencies of both cotton and polyester fabrics are nearly the same. At the equivalence of filtration efficiency and reduction in filter mass of polyester fabrics compared with cotton fabrics explain the increase in the value of $(\eta / M)$. Also when using $100 \%$ polyester fabrics rather than $100 \%$ cotton fabrics leads to decreasing the dust emission or outlet concentration (Co). This may be due to the presence of crimped long fibres of polyester.

\section{(ii) Pile Fabric structure}

The plots $2 n$ F Lqures $(21-38)$ show the effect of fibres type (100\% polyester at the level $x_{1}=1,100 \%$ cotton at $x_{1}=-1$ ) on the specific work of rupture, bursting strength, rate of abrasion, filtration efficiency $(?)$, pressure drap ( $\Delta P$ ), filter perínmance ( $\gamma$ ), filtration efficiency per unit mass ( $(/ / 1)$, specific cake resistance $(K)$ and outlet concentration (Co) for loop pile structure. Plle fabric was the first structure considered appropriate for dust filtration, because it had a low a r permeability and 
Table (5): Response-surface Equations For Interlack Structure

\begin{tabular}{|c|c|}
\hline Response - sur mace Equations - & $(\tau)$ \\
\hline $\begin{aligned} y_{1}= & 0.013+1.648 x_{1}+0.670 x_{2}+0.099 x_{3}+0.045 x_{1} x_{2}+0.215 x_{1} x_{3}- \\
& -0.212 x_{2} x_{3}\end{aligned}$ & 0.9789 \\
\hline $\begin{aligned} y_{2}= & 15.913+0.695 x_{1}+6.213 x_{2}+0.172 x_{3}+0.230 x_{1} x_{2}+0.315 x_{1} x_{3}- \\
& -6.750 x_{2} x_{3}\end{aligned}$ & 0.9999 \\
\hline$y_{3}=6.075-2.1 x_{1}-1.075 x_{2}-0.15 x_{3}+0.5 x_{1} x_{2}-0.225 x_{1} x_{3}-0.85 x_{2} x_{3}$ & 0.9717 \\
\hline $\begin{aligned} y_{4}= & 90.374-0.004 x_{1}+4.199 x_{2}-1.816 x_{3}+0.061 x_{1} x_{2}-0.074 x_{1} x_{3}- \\
& -0.481 x_{2} x_{3}\end{aligned}$ & 0.9911 \\
\hline$y_{5}=12.9-6.65 x_{1}+9.30 x_{2}-0.6 x_{3}-5.55 x_{1} x_{2}+0.95 x_{1} x_{3}-1.5 x_{2} x_{3}$ & 0.9945 \\
\hline $\begin{aligned} y_{6}= & 4.234+1.461 x_{1}-2.246 x_{2}-1.029 x_{3}-0.334 x_{1} x_{2}-0.241 x_{1} x_{3}+ \\
& +0.701 x_{2} x_{3}\end{aligned}$ & 0.9994 \\
\hline $\begin{aligned} y_{7}= & 0.354-0.001 x_{1}-0.079 x_{2}-0.001 x_{3}-0.004 x_{1} x_{2}-0.006 x_{1} x_{3}- \\
& -0.009 x_{2} x_{3}\end{aligned}$ & 0.9970 \\
\hline $\begin{aligned} y_{8}= & 0.881-0.564 x_{1}+0.474 x_{2}-0.063 x_{3}-0.271 x_{1} x_{2}+0.087 x_{1} x_{3}- \\
& -0.307 x_{2} x_{3}\end{aligned}$ & 0.9235 \\
\hline $\begin{aligned} y_{9}= & \left(0.746-0.084 x_{1}-0.436 x_{2}+0.276 x_{3}+0.224 x_{1} x_{2}-0.249 x_{1} x_{3}-\right. \\
& \left.-0.276 x_{2} x_{3}\right) x_{10}-7\end{aligned}$ & 0.9851 \\
\hline
\end{tabular}

high dust retension due to 1 ts unique structure. It is clear that when using $100^{2}$ polyester fabrics increase the specific work of rupture, the bursting strength and filter performance ( 7 ) significantly. Also these figures illur strate that rate of abrasion, filtration efficiency $(7)$, pressure drop ( $\Delta P$ ), specific cake resistance $: K$ ) and out let concentration $(C a)$ decrease when using $100^{\circ}$ polyester faorics. But the improvenent in filtration efficiency with increasing in filter mass explain the equivalence in the value of $(7 / M)$ for soth polyester and cotton knitted fabrics. When using 100\% cotton knitted fabric the value of filtration efficiency increases compared with $100 \%$ polyester knitted fabric. This may be due to the higher halriness of the cotton yarns especially with the help of loop-pile structure.

\section{(iii) Single Piqué Structure}

Figures $(39-56)$ show that both the behaviour of single pique structure is very simalar to the looppile structure wath regard to all of mectanical and filtration properties except specific cake resistance. Also type of fibres has no effect on specific cake resistance. This may be due to the higher fibre diameter of polyester fibre the lower specific cake resistance. in addition t.o this, the collected mass of dist when using polyester fibres is less than cotton knitted fabrcis. Because filtration efficrency of polyester knitt.ed fabrics is less than cotton knitred fabrics. Thus the reduction in specific cake resistance and reduction in filtration efficiency due to coarse fibres (polyester fibres) explain the equivalence in the value of $(K)$ for both polyester and cotton knit:ted fabrics. 

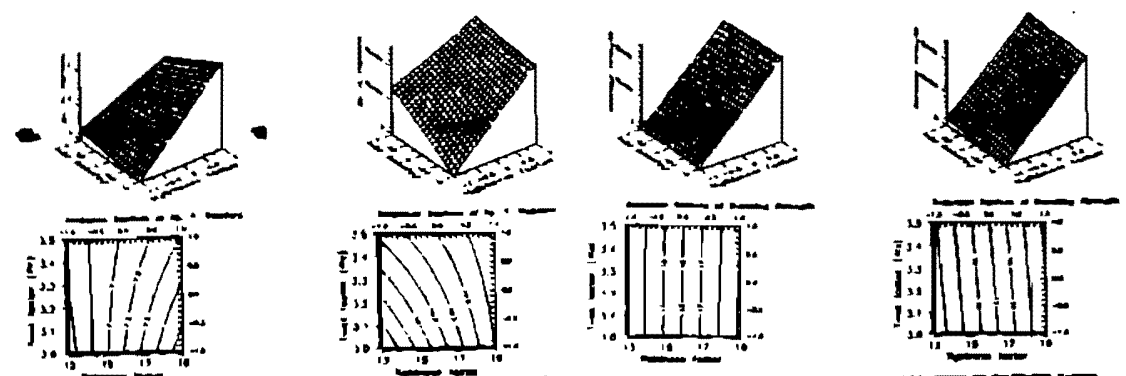

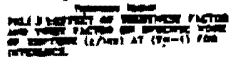
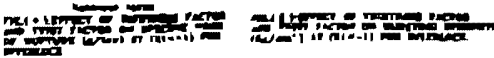

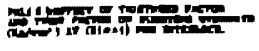
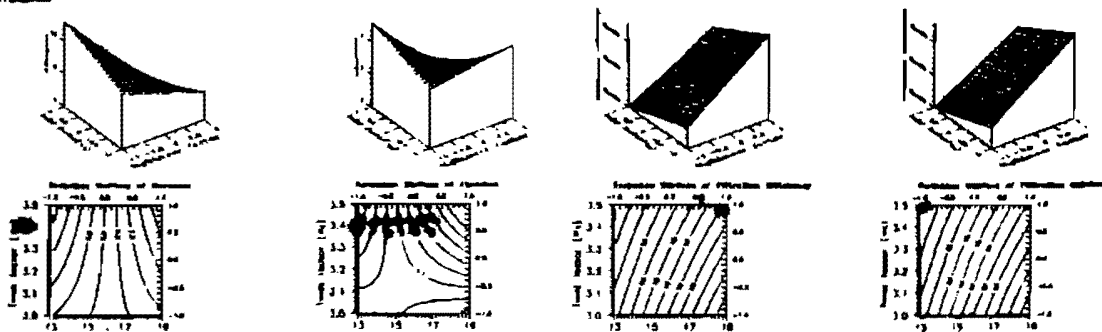

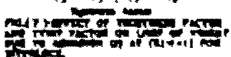
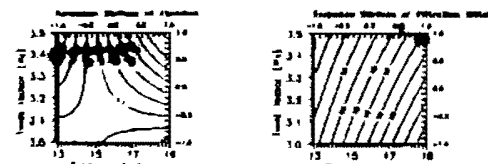

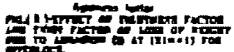

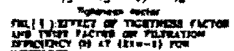
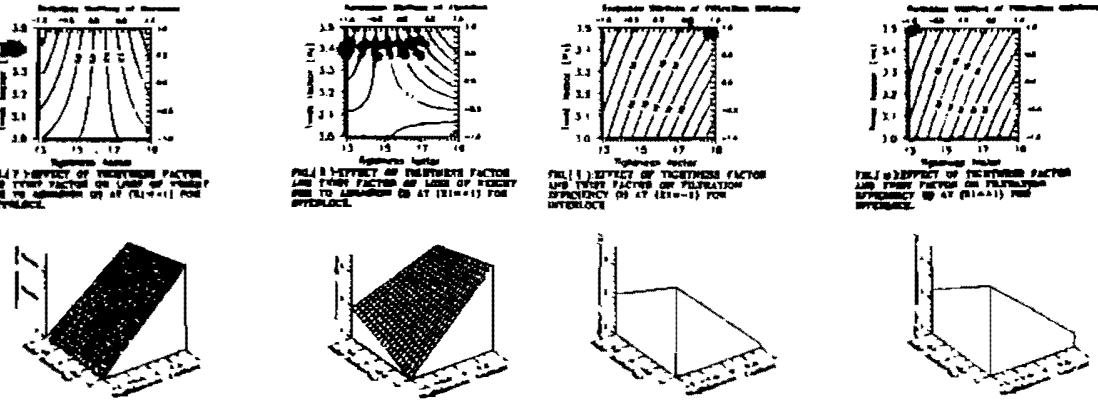

war

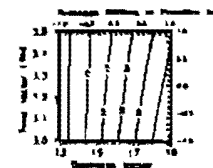

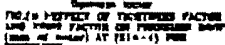

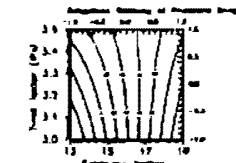

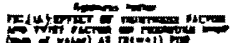
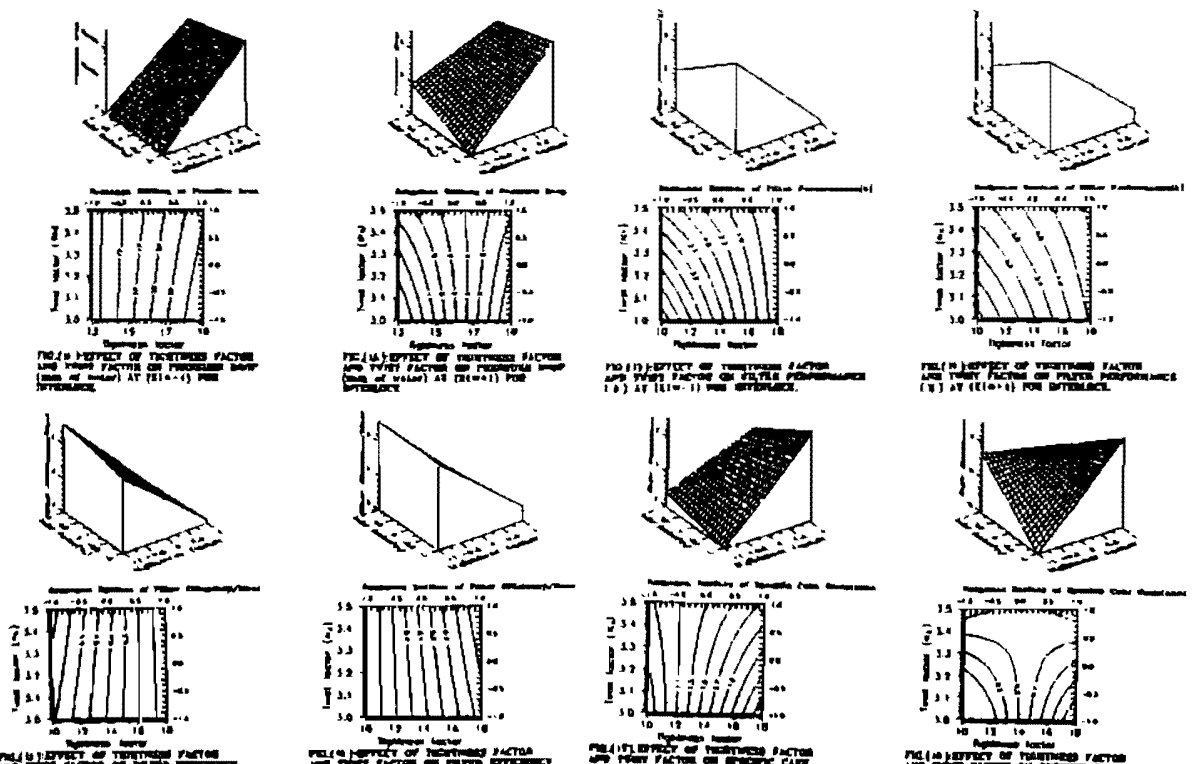

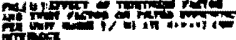
and

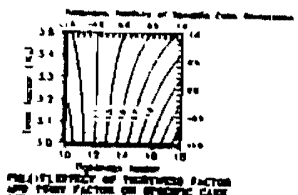

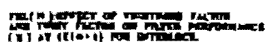
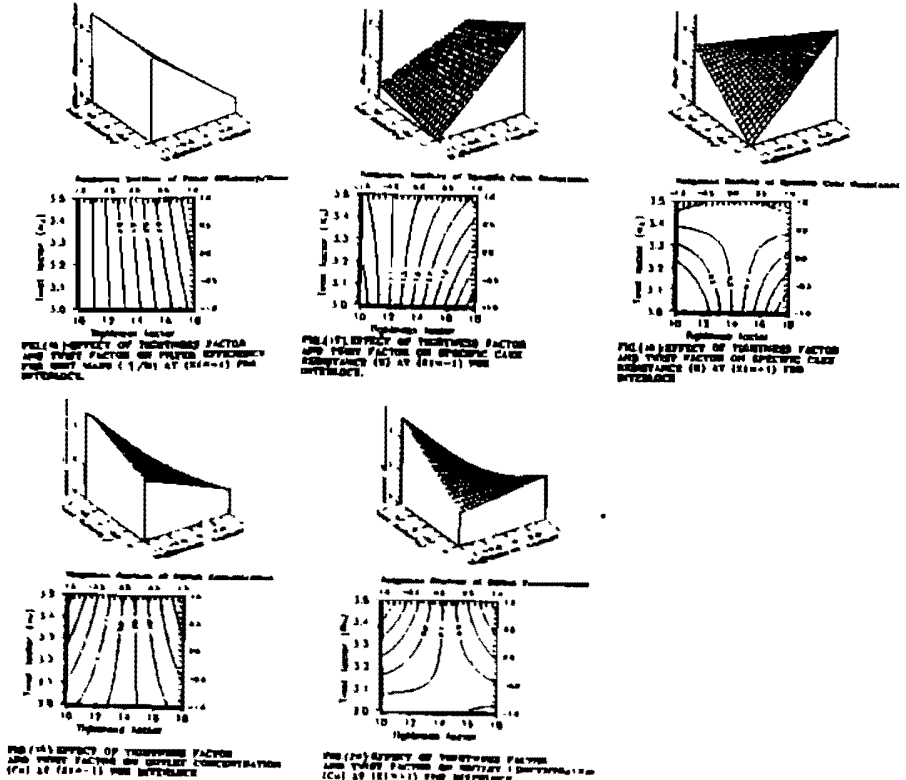

Pew 
3-2-2. T ightness Fsetor:

\section{(i) Inter lack Structure}

- The plots in figures $(3-20)$ show that the specific work of rupture, bursting strength, abrasion rate, filtration efficiency ( $T$ ), pressure drop ( $\Delta P)$, specific cake resistance $(K)$ increase, but $f_{1}$ lter performance $(\gamma)$ and filtration efficiency per unit mass $(\eta / M)$ decrease as fabric tightness increases when using 100\% polyester fabrics at the level $\left(x_{1}=+1\right)$ and viceversa for 100\% cotton fabrics except filter performance $(\gamma)$ and filter efficiency per unit mass $(T / M)$ decrease too. The effect of tightness factor on filter performance can be interpreted in terms of the change of fabric bulk (the reciprocal of fabric density) and the ratıo of fabric thickenss to loop length. And using low fabric bulk results in reducing filter performance ( $\gamma$ ) and $(\eta / M)$. Also because of the high value of loop shape factor (course density/wale density).

\section{(ii) Pile Fabric Structure}

Figures $(21-38)$ show that the specific work of rupture, bursting strength, filtration efficiency $(?)$, pressure drop $(\Delta P)$, filter performmnce ( $\zeta$ ) increase, but rate of abrasıon, ( $\mathrm{Y} / \mathrm{M}$ ) and specıfic cake resistance (K) decrease when using pile fabric structure for $100 \%$ polyester fabrics rather than interlock. The value of filtration efficiency per unit mass ( $q / M$ ) decreases because of the higher surface density of the pile fabric compared with the light interlock. But the disadvantages of 100\% cotton include the higher rate of abrasion and specific cake resistance $(K)$.

\section{(ii)) Single Piqué Structure}

The plots in Figures $(39-56)$ show that for single pique structure with using $100 \%$ polyester fibres specific work of rupture, bursting strength, filtration efficiency ( 7 ), pressure drop ( $\Delta P$ ), filter performance $(\gamma)$, specific cake resistance $(K)$ and out let concentration (Co) increase with increasing fabric tightness factor. This may be due to the space between the front and back of the fabric. Simillary, rate of abrasion and filtration effic iency per unit mass $(\eta / M)$ decreases with increasing tightness factor. The results obtained in the case of single piqué structure can be therefore considered to agree falrly close wath the abtained experimental results in the case of plle fabric structure. Thus, for the three studied structures, when using polyester knitted fabrics they give the langest surface life and the best filter performance compared with the cotton knitted fabrics.

\section{3-2-3. Twist Multiplier:}

(1) Inter lock Structure

The plots in figures $(3-20)$ show that for interlock structure with using $100 \%$ polyester, specific work of rupture, bursting strength inc ease with increasing twist factor. This may be due to the close packing of loops in the case of hightwisted yarn (twist multiplier 3.5). But filtration properties are distorted with increasing twist factor. But when using 100\% cotton knit.ted fabric, there is a marginal effect of twist level on both mechanical and filtration properties. This may be due to the hardness of this structure, which the loops on the face are opposing those on the back.

\section{(1i) Pile Fabrıc Structure}

Figures $(21-38)$ show that when using $100 \%$ polyester fabrics, mechanical properties are distorted with increasing twist factor but the vice versa when using $100 \%$ cotton fabrics. This may be due to increasing the inclination angle of polyester fibres on the yarn axis when increasing the twist factor, this led to weaking the yarns. But filtration properties improve with increasing twist factor. This may be due to reducing air volds between the fibres themselves also the pile loops capture the particles of dust easily. 
Iable (6): Response-aur face Equations For Pule Fabrics

\begin{tabular}{|c|c|}
\hline Respond-surface Equations & (r) \\
\hline $\begin{aligned} y_{1}= & 2.55+0.255 x_{1}+0.05 x_{2}-0.075 x_{3}-0.025 x_{1} x_{2}-0.1 x_{1} x_{3}- \\
& -0.025 x_{2} x_{3}\end{aligned}$ & 1.000 \\
\hline $\begin{aligned} y_{2}= & 8.625+0.475 x_{1}+1.85 x_{2}-0.050 x_{3}-0.05 x_{1} x_{2}-0.20 x_{1} x_{3}- \\
& -0.075 x_{2} x_{3}\end{aligned}$ & 0.9959 \\
\hline $\begin{aligned} y_{3}= & 7.25-1.55 x_{1}-0.325 x_{2}+0.225 x_{3}-0.575 x_{1} x_{2}+0.175 x_{1} x_{3}- \\
& -0.2 x_{2} x_{3}\end{aligned}$ & 0.9603 \\
\hline $\begin{aligned} y_{4}= & 91.063+0.262 x_{1}+2.913 x_{2}-1.112 x_{3}+0.013 x_{1} x_{2}-1.113 x_{1} x_{3}- \\
& -1.463 x_{2} x_{3}\end{aligned}$ & 0.9297 \\
\hline $\begin{aligned} y_{5}= & 11.275-3.225 x_{1}+5.025 x_{2}-0.225 x_{3}-2.375 x_{1} x_{2}+ \\
& +0.075 x_{1} x_{3}-0.375 x_{2} x_{3}\end{aligned}$ & 0.9995 \\
\hline $\begin{aligned} y_{6}= & 2.397+0.071 x_{1}-0.491 x_{2}+0.423 x_{3}+6.573 x_{1} x_{2}+0.394 x_{1} x_{3}- \\
& -0.654 x_{2} x_{3}\end{aligned}$ & 0.9310 \\
\hline $\begin{aligned} y_{7}= & 0.289-0.006 x_{1}-0.069 x_{2}-0.001 x_{3}+0.006 x_{1} x_{2}-0.011 x_{1} x_{3}- \\
& -0.009 x_{2} x_{3}\end{aligned}$ & 0.9876 \\
\hline $\begin{aligned} y_{B}= & 0.476-0.009 x_{1}+0.259 x_{2}+0.154 x_{3}-0.171 x_{1} x_{2}-0.096 x_{1} x_{3}+ \\
& +0.161 x_{2} x_{3}\end{aligned}$ & 0.9728 \\
\hline $\begin{aligned} y_{9}= & \left(0.344-0.049 x_{1}-0.101 x_{2}+0.084 x_{3}+0.026 x_{1} x_{2}-0.029 x_{1} x_{3}-\right. \\
& \left.-0.096 x_{2} x_{3}\right) \times 10^{-7}\end{aligned}$ & 0.9257 \\
\hline
\end{tabular}

Table (7): Response-surface Equations far Sinqle Piqué

\begin{tabular}{|c|c|}
\hline Response - surface Equat ions & (r) \\
\hline $\begin{aligned} y_{1}= & 5.474+0.524 x_{1}-0.016 x_{2}+0.114 x_{3}-0.221 x_{1} x_{2}+0.164 x_{1} x_{3}- \\
& -0.211 x_{2} x_{3}\end{aligned}$ & 0.9125 \\
\hline$y_{2}=14.7+1.7 x_{1}+3.2 x_{2}+0.05 x_{1} x_{2}-0.05 x_{1} x_{3}-0.15 x_{2} x_{3}$ & 0.9999 \\
\hline $\begin{aligned} y_{3}= & 7.245-2.005 x_{1}-0.505 x_{2}-0.795 x_{3}-0.055 x_{1} x_{2}-0.095 x_{1} x_{3}- \\
& -0.145 x_{2} x_{3}\end{aligned}$ & 0.9469 \\
\hline $\begin{aligned} y_{4}= & 90.963-1.688 x_{1}+4.738 x_{2}-1.887 x_{3}+2.338 x_{1} x_{2}+2.862 x_{1} x_{3}- \\
& -0.413 x_{2} x_{3}\end{aligned}$ & 0.9709 \\
\hline$y_{5}=5-x_{1}+1.45 x_{2}-0.10 x_{3}-0.45 x_{1} x_{2}+0.1 x_{1} x_{3}-0.25 x_{2} x_{3}$ & 0.9909 \\
\hline $\begin{aligned} y_{6}= & 5.770+0.478 x_{1}-0.327 x_{2}-0.748 x_{3}+0.783 x_{1} x_{2}+0.737 x_{1} x_{3}+ \\
& +0.068 x_{2} x_{3}\end{aligned}$ & 0.9113 \\
\hline $\begin{aligned} y_{7}= & 0.386-0.016 x_{1}-0.099 x_{2}-0.014 x_{3}+0.014 x_{1} x_{2}+0.009 x_{1} x_{3}- \\
& -0.004 x_{2} x_{3}\end{aligned}$ & 0.9981 \\
\hline $\begin{aligned} y_{8}= & 0.035+0.005 x_{1}+0.003 x_{2}+0.008 x_{3}-0.003 x_{1} x_{2}-0.003 x_{1} x_{3}+ \\
& +0.005 x_{2} x_{3}\end{aligned}$ & 0.9999 \\
\hline $\begin{aligned} y_{9}= & \left(2.531-0.796 x_{1}-1.676 x_{2}+1.049 x_{3}+0.756 x_{1} x_{2}-0.619 x_{1} x_{3}-\right. \\
& \left.-1.349 x_{2} x_{3}\right) \times 10^{-7}\end{aligned}$ & 0.9695 \\
\hline
\end{tabular}



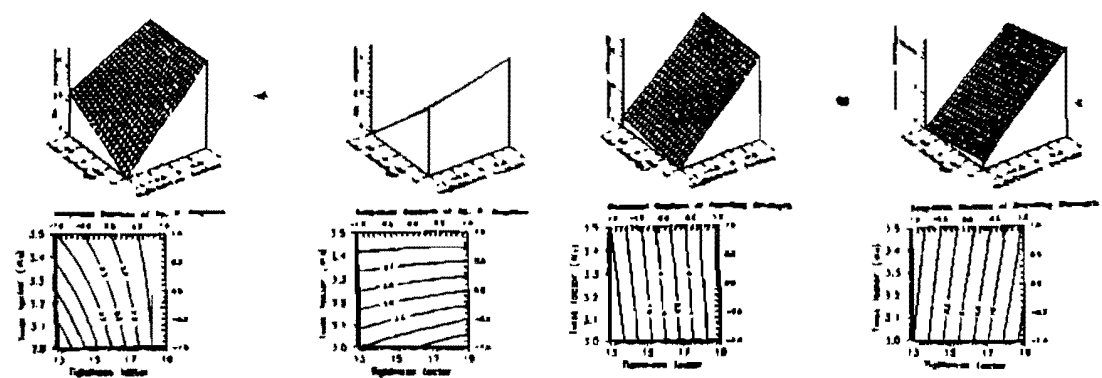

sing

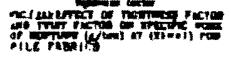

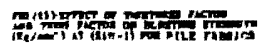
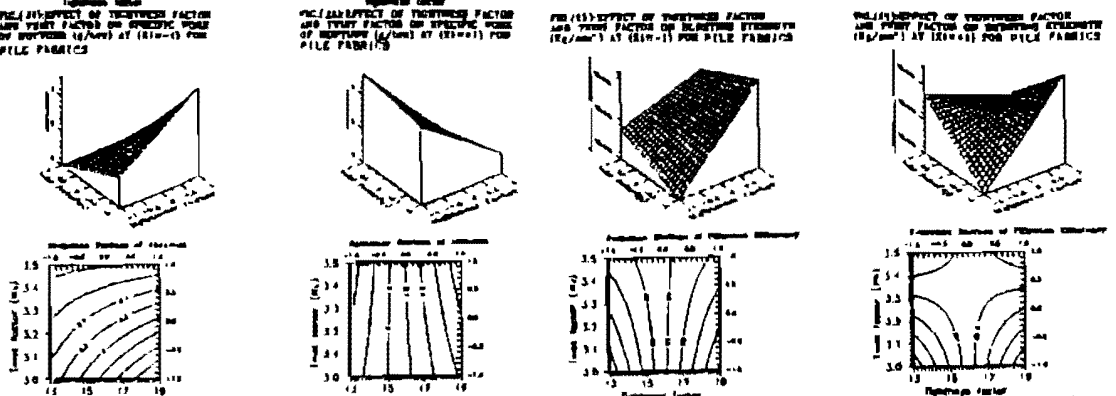

itition
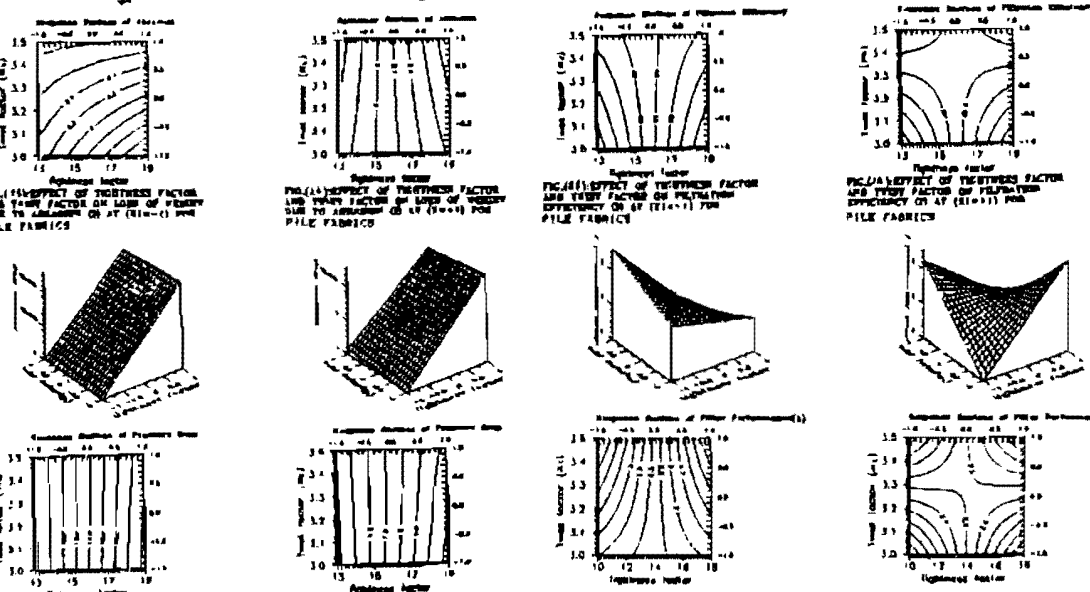

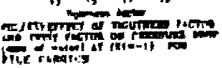
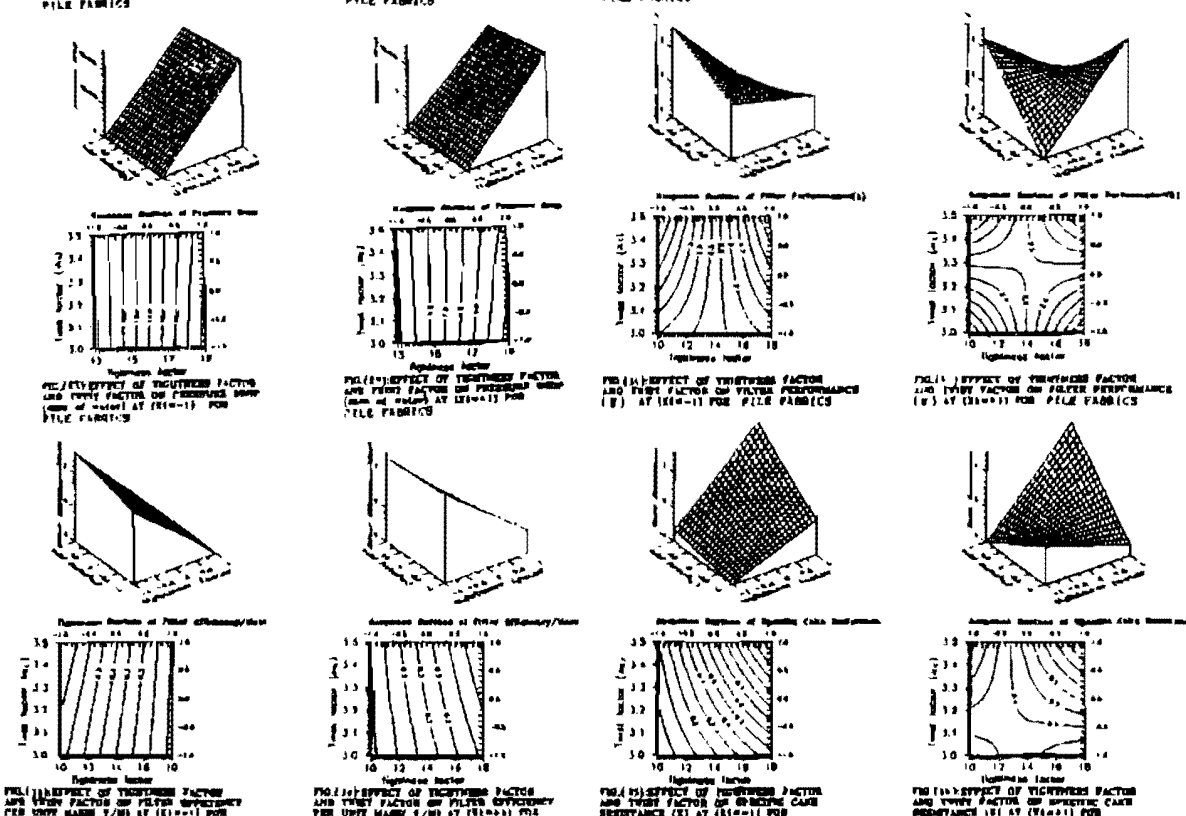

isis

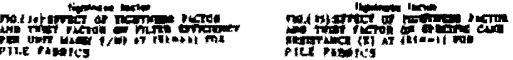
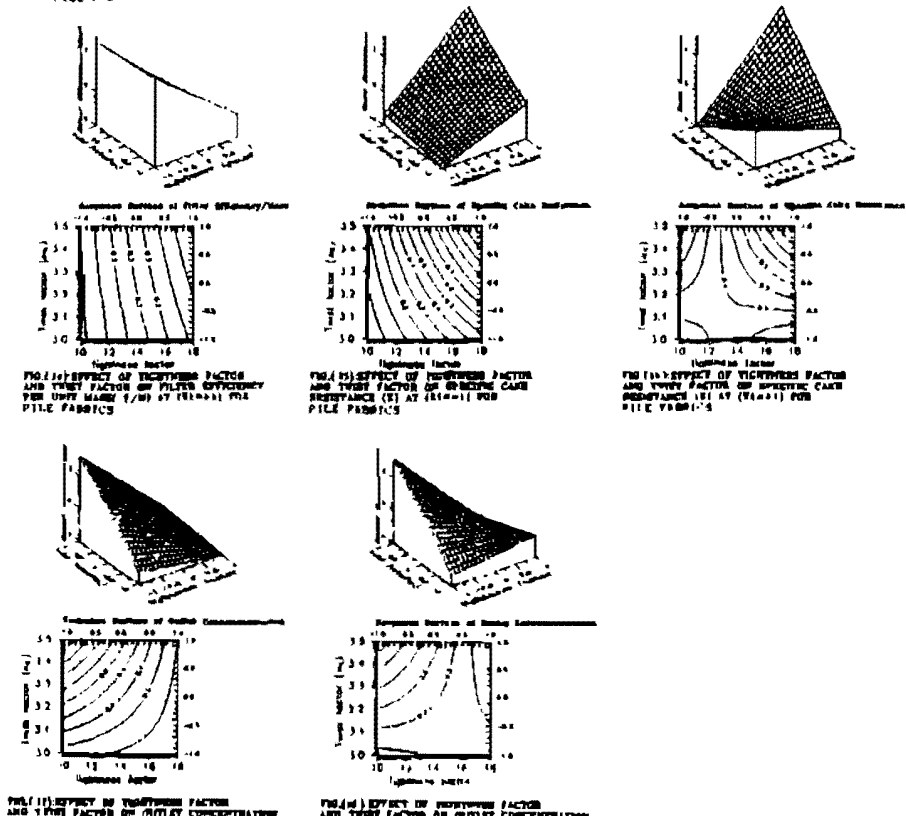

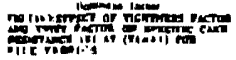

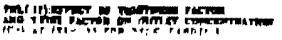

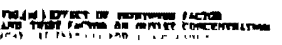



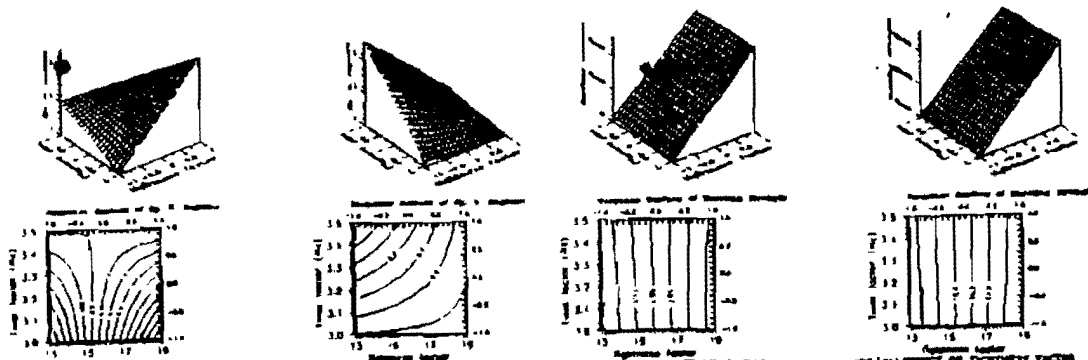

(n)
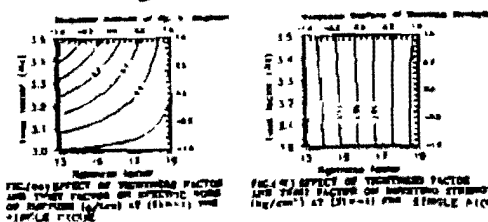

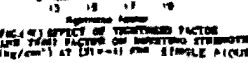
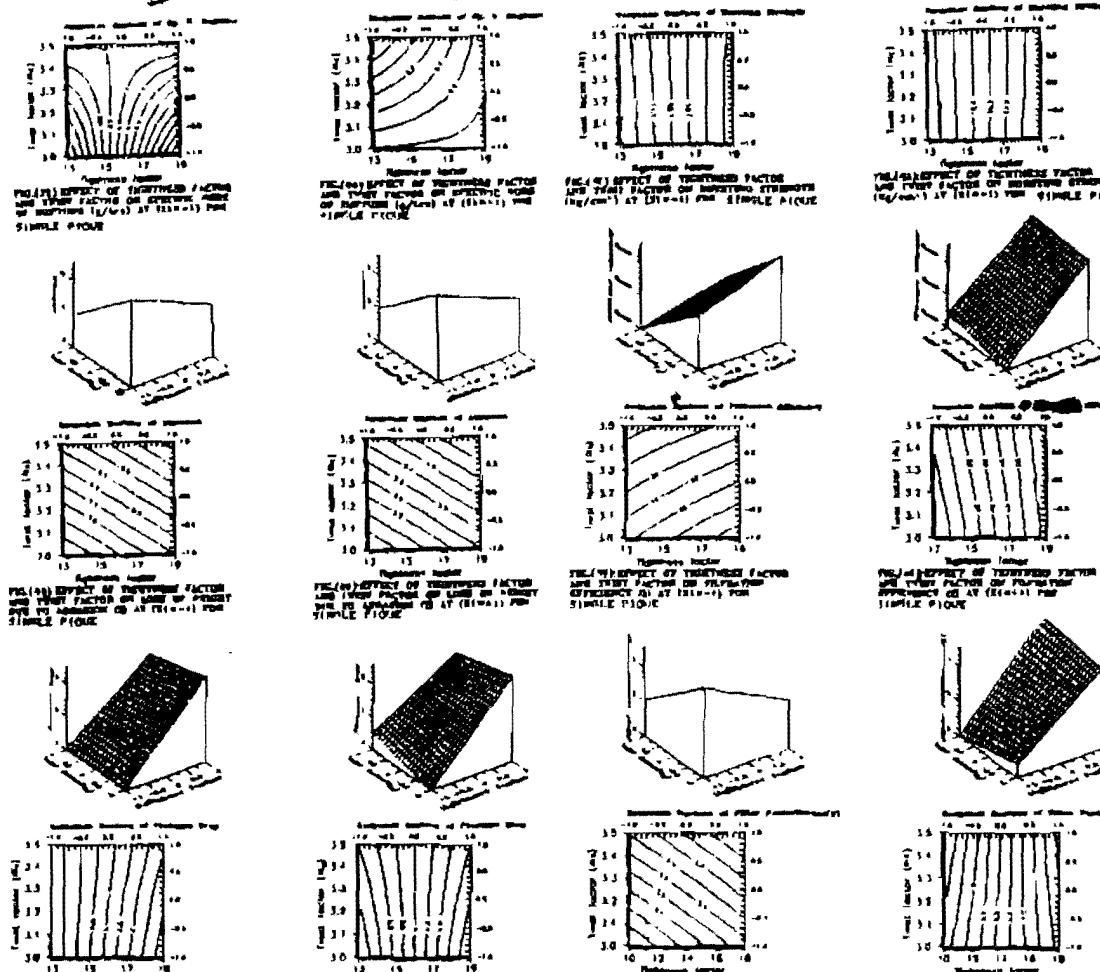

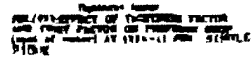
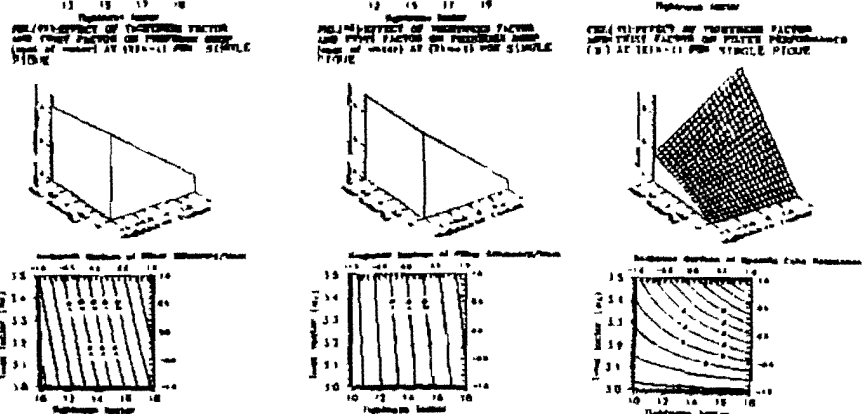

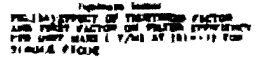

siming
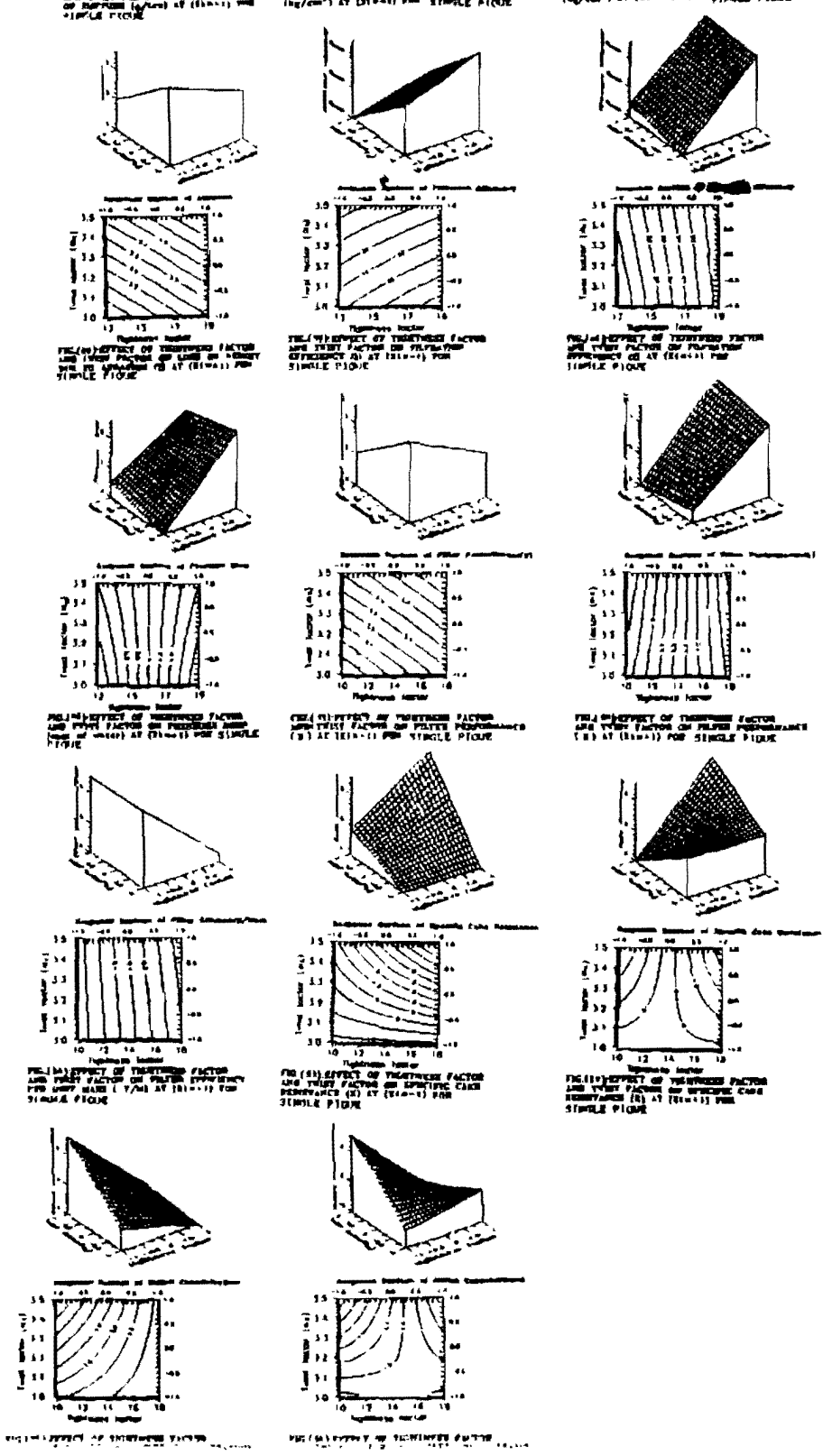

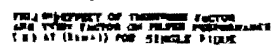
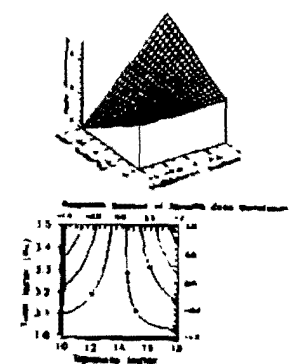
s.

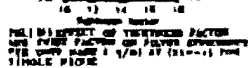




\section{(1ii) Single Piqué Structure}

The plot in Figures $(39-56)$ show that when using both 100\% polyester and 100\% cotton knitted fabrics, specific work of rupture increases as yarn lwist factor increases. This may be due to the increase of normal pressure force on the yarn axis and consequently the cohesion of fibres within the yarn. But filtration properties of $100 \%$ polyester knitted fabrics tend to move as yarn twist factor increases compared with 100\% cotton fabrics. This may be due to linking the front and back loops. Also when air pressure is applied, therefore, both sets of loops opposing each other are compressed and due to the space between the fronl and back of the fabruc. Also it is more easy to compress these than the rest structures.

\section{3-3. Mathematical Solution:}

By using the computer all nine nonlinear equations for each structre are solved and one result could be printed as one optimum solution for the nine ecuations. Table $(\theta)$ shows the typical computer solution for the nine equations.

Thus, these computed optımum factors can be used to desıgn a new tubular filter for protecting the workers in spinning malls from the alr polit tion.

3-4. A Comparison of The Performanceg of Knitted and Conventional Woven filters:

From such study performance properties of filter fabrics can be divlded into two groups: positive propecties such as specific wack of rupture, bursting pressure, filtration efficiency $(7)$, filter performance $(\zeta)$ and filter performance per unit mass ( $7 / M$ ); and negative properties such as rate of abrasion, pressure drop $(\Delta P)$, specific cake resistance $(K)$ and outlet concentration (Co). Relative characteristics of each property could be calculated by the following equations and listed in lable ( 9 ):

$$
\begin{aligned}
& \text { positive relative characteristics }(q)=\frac{x_{1}}{x_{\max }} \\
& \text { and negative relative characteristics }(q)=\frac{x_{\frac{m}{1 n}}}{x_{1}} \\
& \text { where } x_{1} \text {-typical value of each property; } \\
& x_{m L n}, x_{\text {max }} \text { min }
\end{aligned}
$$

\begin{tabular}{|c|c|c|c|c|c|c|c|}
\hline \multirow{2}{*}{\multicolumn{2}{|c|}{ St ructure }} & \multicolumn{2}{|c|}{ Interlock } & \multicolumn{2}{|c|}{ Pile Fabric } & \multicolumn{2}{|c|}{ Single Piqué } \\
\hline & & Level & Value & Level & Value & Level & Value \\
\hline $\begin{array}{l}\text { Optimum } \\
\text { Factors }\end{array}$ & $\begin{array}{l}x_{1} \\
x_{2} \\
x_{3}\end{array}$ & $\begin{array}{r}1.0 \\
0.2 \\
-0.8\end{array}$ & $\begin{array}{c}100 \% \text { Polyester } \\
14.514 \\
3.05\end{array}$ & $\begin{array}{r}0.5 \\
-0.2 \\
0.9\end{array}$ & $\begin{array}{c}75 \% P / 25 \% \mathrm{C} \\
12.056 \\
3.475\end{array}$ & $\begin{array}{r}-0.8 \\
1.0 \\
-1.0\end{array}$ & $\begin{array}{c}10 \% P / 90 \% \mathrm{C} \\
21.73 \\
3\end{array}$ \\
\hline $\begin{array}{l}\text { or responded } \\
\text { Parameliers }\end{array}$ & $\begin{array}{l}y_{1} \\
y_{2} \\
y_{3} \\
y_{4} \\
y_{5} \\
y_{6} \\
y_{7} \\
y_{8} \\
y_{9}\end{array}$ & & $\begin{array}{l}0.387 \\
8.587 \\
4.2^{\circ} 6 \\
2.763 \\
6.960 \\
5.083 \\
0.343 \\
0.385 \\
0.646 \times 10^{-7}\end{array}$ & & $\begin{array}{l}.562 \\
.376 \\
.915 \\
.361 \\
.149 \\
149 \\
.295 \\
503 \\
.417 \times 10^{-7}\end{array}$ & & $\begin{array}{l}5.440 \\
6.610 \\
9.164 \\
9.770 \\
8.040 \\
5.712 \\
0.314 \\
0.021 \\
0.692 \times 10^{-7}\end{array}$ \\
\hline
\end{tabular}

Table (8:: Solution of Equations For Each Structure 
The melhod chosen here to represent the resuts graphicaly was the use of a polar diagram. Each property chosen as contributing to the total expression of the performance of a filter fabric was allocated a radial axis, upon which were plotted the relative characteristics obtained from testing the fabrics as shown in Table (9) and $F \mathrm{ig}$. (57). The values plotted were joined by using straight lines to produce a profile for each fabric tested.

Therefore, this plot can be used for assessing the quality of different filter fabrics by calculating the polygon area for each structure. in inclusive coefficient of filtration performance (1) can be calculated as follows:

$$
I=\left(A / A_{\max }\right) \times 100, \%
$$

where A polygon area of every structure at various properties with nine triangles ( $F 1 g .57$ ) and $2 \mathrm{~L}$ can be calculated by the following formula:

$$
\begin{aligned}
& A=0.5(\sin 360 / 9)\left(a_{1} a_{2}+a_{2} a_{3}+q_{3} a_{4}+q_{4} a_{5}+q_{5} a_{6}+q_{6} a_{7}+q_{7} a_{8}+\right. \\
& \left.a_{8} a_{9}+a_{9} a_{1}\right) \quad \ldots \ldots(10) \\
& A_{\text {max }} \text { max. polygon area when } q_{1}=a_{2}=a_{3}=q_{4}=q_{5}=q_{6}=q_{7}=q_{8}= \\
& a_{9}=1 \text {, i.e. }\left(A_{\text {max }}=2.893\right)
\end{aligned}
$$

For selecting the best fabric structure the suggested method mentioned above (polygon area) could be applied as shown in lable ( 9 ) and $F_{19}$. (57). The results obtained show that interlock structure made of $100 \%$ polyester fibres with 14.51 tightness factor and $3.05 \alpha e$ twist multiplier has the highest filtration performance compared with the other structures. Ihus interlock structure exhibits much greater filtration cerformance than that of comparable fabrics.

Also both knitted and conventional woven filters were used as a filter material in a domestic vacuum cleaner which has maximum dust extraction efficiency at a relatively low pressure drop and is not costly. The values of filtration efficiencies $(7)$ and $(7 / M)$ obtained for the conventional woven and knitted filters could be comcared as listed in rable (10). Filtration efficlency was measured using Japanese vacuum cleaner and actual fly and dust extracted from the opening and cleaning lines. The values of $f_{1}$ ltration effi-ctenc) ( 7 ) show that the knitted filters are more effective in retaining fly and dust especially sample (2A) which has $99.5 \%$ filtration efficiency.

Table (9): Relatıve Performence Characterıstics of Filter Fabrics

\begin{tabular}{c|c|c|c|c}
\hline \multirow{2}{*}{$\begin{array}{c}\text { Relative } \\
\text { Propecty }\end{array}$} & \multicolumn{4}{|c}{ Fabric Structure } \\
\cline { 2 - 5 } & Interlack & Pile Fabric & Single Piqué & Conv. Woven \\
\hline$q_{1}$ & 1 & 0.247 & 0.524 & 0.131 \\
$q_{2}$ & 0.784 & 0.365 & 0.723 & 1 \\
$q_{3}$ & 1 & 0.621 & 0.469 & 0.095 \\
$q_{1}$ & 0.930 & 0.896 & 1 & 0.961 \\
$q_{5}$ & 1 & 0.854 & 0.866 & 0.773 \\
$q_{9}$ & 1 & 0.519 & 0.939 & 0.584 \\
$q_{9}$ & 0.722 & 0.620 & 0.661 & 1 \\
$q_{g}$ & 0.055 & 0.042 & 1 & 0.040 \\
$q_{9}$ & 0.645 & 1 & 0.602 & 0.938 \\
\hline Polygon Area (A) & 1.887 & 0.873 & 1.628 & 0.738 \\
(I), \% & 65.2 & 30.2 & 56.3 & 25.5 \\
\hline
\end{tabular}



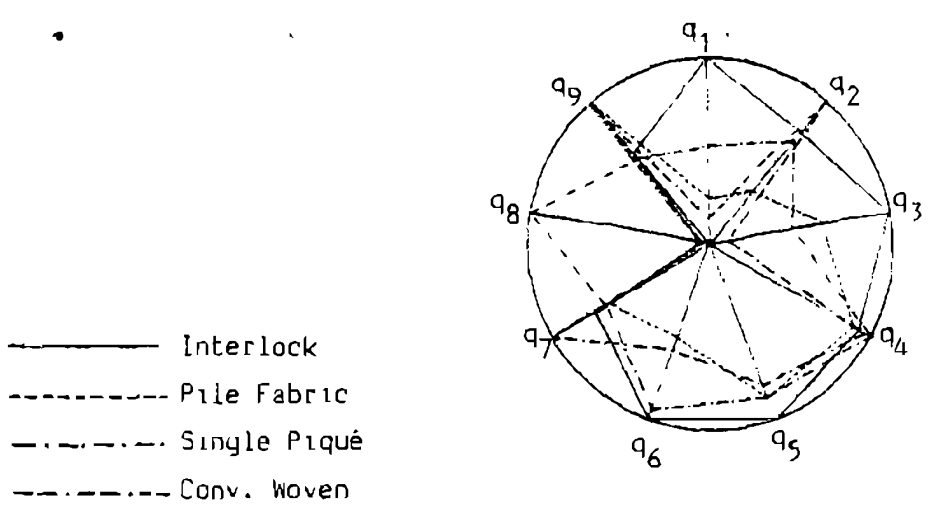

Fig. $(57)$ : Product-quality Polygons For Relative Characteristics in rabie( 9 )

Table (10): A Comparisun of The Performances of Knitted and Conventional Woven Filters

\begin{tabular}{|c|c|c|c|c|}
\hline \multirow{2}{*}{$\begin{array}{c}\text { Sample } \\
\text { Cade }\end{array}$} & \multicolumn{2}{|c|}{ In Laboratory Test } & \multicolumn{2}{|c|}{ In Operating Conditions } \\
\hline & $7,\left(\begin{array}{l}0 \\
0 \\
0\end{array}\right)$ & $7 / M$ & $\eta,\left(\begin{array}{l}0 \\
s\end{array}\right)$ & $7 / M$ \\
\hline $\begin{array}{l}2 A \\
4 A \\
4 B \\
5 B \\
78 \\
8 B \\
3 C \\
4 C\end{array}$ & $\begin{array}{l}96.2 \\
92.9 \\
90.8 \\
86.2 \\
85.0 \\
92.0 \\
84.3 \\
91.5\end{array}$ & $\begin{array}{l}0.288 \\
0.265 \\
0.212 \\
0.328 \\
0.339 \\
0.205 \\
0.487 \\
0.273\end{array}$ & $\begin{array}{l}99.5 \\
96.6 \\
91.7 \\
88.3 \\
90.6 \\
94.6 \\
86.5 \\
94.0\end{array}$ & $\begin{array}{l}3.298 \\
0.276 \\
0.214 \\
0.336 \\
0.361 \\
0.211 \\
0.500 \\
0.280\end{array}$ \\
\hline $\begin{array}{l}\text { Conv. } \\
\text { Filter }\end{array}$ & 95.9 & 0.475 & 96.6 & 0.478 \\
\hline
\end{tabular}

\section{CONCLUSION}

From the results obtained in the present work, the following conclus lons can be drawn cut:

1- Knitted fabrics made of $100 \%$ polyester fibres offer properties different frcm those of all-cotton fabrics, to an extent depending on the type of structure.

2- The us ung of 100\% polyester knitted fabrics provides a remarkable improvement in both the mechanical and filtration properties compared with $100 \%$ cotton fabrics.

3- Both tightness factor and twist multiplier affecl: to a great. extent on mechanical and filtration properties.

4- For all polyester sl ructures, specific work oi rupture, bursting presisure, filtraticn efficienc), pressure drop and sperific cake resistance increase but $f i l t e r$ performance $(\gamma)$ and $f_{1}$ itration efficiency per unit mass decrease as tightness factor increases. Conversley, rate of abrasion decreases and filter performance $(\gamma)$ increases as tightness factor increases especially for both pile fabric and single piqué structures.

5- Twist multiplier of knit.ted yerns affects with a different. tiends on soth mechanical and filtcation properties according to the type of structure. 
$G$ The filtration efficiency of the fabric composed of $100 \%$ polyester is higher than the filtration efficiency of $100 \%$ cotton fabric by about $0.04 \%$ for interlockstructure ande. 7\% for pile fabric and $6 \%$ for single piqué structure.

7- Conventional woven filters had high dust emission as well as high pressure drop, which were not considered to be acceptable for efficient filters.

8- The most sultable structure is interlock which has a max filtration efficrency at a celatively low pressure drop and us rot costly. But the other structures are less efficient dust extractors and have a larger pressure drop on the fabric which makes them less suitable for extracting dust from the alr.

q- Filter fabrics must meet specific requirements so that the development and the production of new filter materials for tubular filter sleeves is of considerable importance for the improvement of the filtration process and for a reduction in its cost.

- 10- The dust-reterit ion efficiencies o interlock knitted fabrics were considerably higher than those of the conventional woven fabrics.

11- An interlock knitted fabric (sample $2 A$ ) composed of $100 \%$ polyester, 17.47 tightness factor ( 20 Ne yarn count, $0.31 \mathrm{~cm}$ loop length) and $3 \alpha$ e twist multiplier is well suited for manufacturing cylindrical filters.

\section{ACKNOWLEDGEMENTS}

The author would like to thank Assoc. Prof. Dr. Mohamed Saad of Calro International Research Centre for providing the knitted yarns and the manager of Calro Carments and Knitting Company (Tricona) for manufacturing the different knitted structures. He also acknowledges the assistance of Eng. Nehal El-Ghandnur for carrying out fabric measurements.

\section{REFERENCES}

1. Claassen B.J. and Barıl A., Text. Res. J., 1981, Vol. 51, No. 2, p.(101105)

2. Anand S.C. and Lawton P.J., J. Text. Inst., 1991, Vol. 92, No. 3, p.(297308 ).

3. Jacobsen J.R., Knitt. Int., 1981, Vol. 88, June, p. 57 through J. Text. Inst. 1991, Vol. 82, No. 3, p. 297.

4. "The Measurement and Control of Knitted Dimensions". H.A.T.R.A. Bulletin Vol. 2, No. 5, p. 108 .

5. Solaveov A.N., "Design of Experiments and Analysis of Results", U.S.S.R., Moscow, 1974, p. 94.

6. Sevsteanov A.G., "Methods and Means of Invest igating Mechanical - Technological Processes of Textıle Industry", U.S.S.R., Moscow, 1980, p. 130.

7. Knapton J.J.F. and Lo. F.W.K., Textile Institute and Industry, 1975, Vol. 13, No. 11 , p. $(355-359)$.

8. Hearle J., Crosberg P. and Backer S. "Structural Mechanics of Fibres, Yarns and Fabrics", W1 ley-interscience, ch. 8, P. 312, 1969.

9. Ibrahim 5., El-Messiery M., Abour Taleb H., Salama M. and Mostafa N., The Indian Textile Journal, June 1992, p. (94-99).

10. Chen C.Y., Chem. Rev., 1956, Vol. 66, p. 595.

11. Evans D.J., Lipson M. and Mayfield R.J., J. Textıle Inst., 1975, Vol. 66, No. 9 , p. $(325-334)$.

12. Ceorge E.R. Lamb, Peter Costanza and Bernard Miller, Text. Res. J., 1975, Vol. 45, No. 6, p. $(452-463)$. 